\title{
Space migrants
}

\section{Migrantes espaciales}

\author{
BORTONI-ANZURES, Liborio $\dagger^{*} \&$ HERRERA-RIVAS, Hiram
}

Universidad Politécnica de Victoria. Departamento de Mecatrónica

ID $1^{\text {st }}$ Author: Liborio, Bortoni-Anzures / ORC ID: 0000-0003-2025-4369, CVU CONACYT ID: 92743

ID $1^{\text {st }}$ Coauthor: Hiram, Herrera-Rivas / ORC ID: 0000-0002-2650-8932, CVU CONACYT ID: 239772

DOI: 10.35429/EJROP.2019.8.5.1.6

Received March 28, 2019; Accepted June 30, 2019

\begin{abstract}
Man has dreamed of stars since their origins, they have inspired hundreds of great thinkers, artists and religious to understand why they are there, to understand how the celestial map changed night after night, imagining that we could reach them and find new and fantastic worlds, as well as unthinkable flora and fauna. Progressively, as science and technology advance, we can feel that those dreams are closer and closer to being realized. Today we are mainly focused on conquering Mars and although still distant, this idea starts to sound feasible. Using probes and terrestrial drones, we have been able to see the planet, decisive and transcendental steps, but they are the beginnings of a great sequence of necessary objectives before a human being can call the red planet "home". This article addresses the main challenges and obstacles that we would have to overcome in order to start an exodus to Mars, such as development of space vehicles, habitats, and environmental suits, generation of oxygen, water, food and energy, as well as essential genetic modifications.
\end{abstract}

Space, Planets, Man Kind

\begin{abstract}
Resumen
El hombre ha soñado con las estrellas desde sus orígenes, han inspirado a cientos de grandes pensadores, artistas y religiosos para comprender porque están ahí, entender como el mapa celeste cambiaba noche tras noche, imaginando si algún día podrían ser alcanzadas y encontrar nuevos y fantásticos mundos, así como flora y fauna impensables. Progresivamente, conforme la ciencia y tecnología avanzan, se siente que esos sueños están cada vez más cercanos a realizarse. Hoy la humanidad se ha enfocado en conquistar Marte y aunque aún distante, esta idea empieza a sonar factible. Empleando sondas y drones terrestres ya ha sido posible asomarse al planeta, pasos decisivos y trascendentales, pero son los inicios de una gran secuencia de objetivos necesarios antes de que un ser humano pueda llamar "casa" al planeta rojo. En este artículo se abordan los principales retos y obstáculos que se tendrían que salvar para poder iniciar un éxodo a Marte, tales como desarrollo de vehículos espaciales, hábitats, trajes ambientales, generación de oxígeno, agua, alimentación y energía, así como modificaciones genéticas indispensables.
\end{abstract}

\section{Espacio, Planetas, Humanidad}

Citation: BORTONI-ANZURES, Liborio \& HERRERA-RIVAS, Hiram. Space migrants. ECORFAN Journal-Republic of Paraguay. 2019, 5-8: 1-6.

\footnotetext{
* Correspondence to Author (email: lbortoni@upv.edu.mx)

$\dagger$ Researcher contributing first author.
} 


\section{Introduction}

Audacious adventures accompanied by incomprehensible technology, magic, fantastic beings, unimaginable landscapes and great riches are the ingredients to conform to science fiction, a literary genre that has inspired man for generations. Although the term science fiction was coined in 1929 by Hugo Gernsback, editor of one of the first magazines of the genre and that defined science fiction as "fantastic narratives interspersed with scientific facts and prophetic visions".

However, the Syrian writer Luciano de Samósata (125-192) was one of the great satirical writers of antiquity, in his work "True stories" narrates how he himself and his companions who leave to navigate the Western Ocean; soon the ship leaves the sea and, sailing through the air, until it reaches the moon; (figure 1) after a long stay between, the selenitas, the ship returns again to the sea, continuing its adventures.

The list of works related to the journey to space is endless, and at the same time, progressively an intrinsic relationship between technology, knowledge and fiction, have come to solve some of the problems posed by the fact of leaving this world, and at the same time some new challenges have been discovered, but it is still far from being able to conquer another planet, much has been advanced since that humble beginning in which the first earthlings managed to travel out of the atmosphere in 1947 , even if they were only a group of flies of the fruit.

There is already an orbital camping house, located $400 \mathrm{~km}$ high, in which since 2000 it has been inhabited by crews that in some cases have managed to stay up to a continuous year, it is only necessary to build a vehicle that achieves approaching the speed of light, discover how to reverse cryogenics, and it would not be too bad to also get artificial gravity, teleportation, food replicators, holographic salons, and universal translators.

How to deal with neighboring species, will we get to mix? Will they end up with us or us with them ?, It is difficult to have tolerance between individuals of our own societies, probably the coexistence with aliens is something more rough.

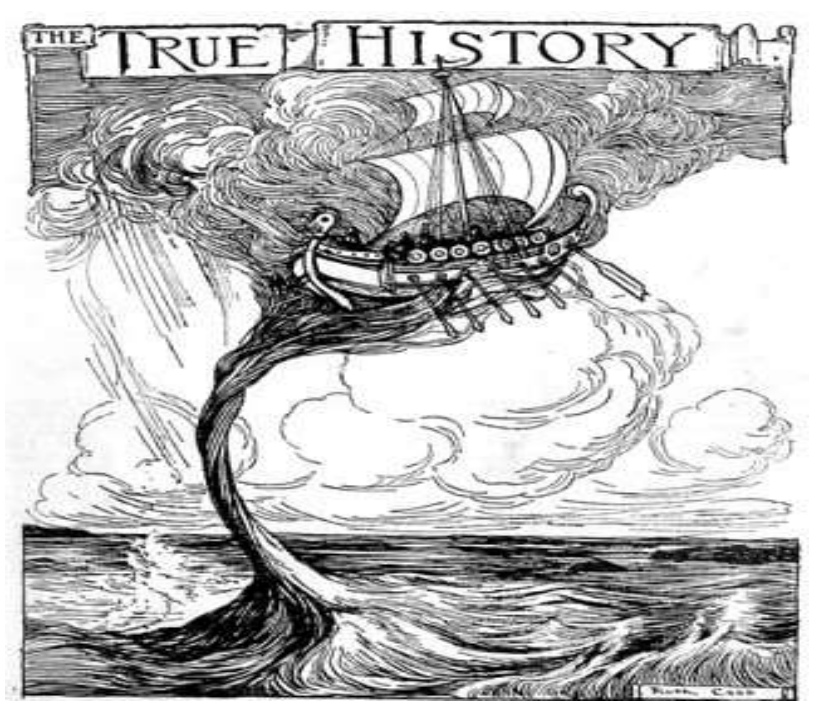

Figure 1 "True stories" on the way to the Moon. Luciano from Samósata

\section{Honey moon on the moon}

After achieving a round trip to the moon in 1969, it was speculated that once it was possible for vacationers to spend a weekend on the moon, with this in mind the space vehicles were designed so that one day they could operate as a commercial airline, the first of which was the "Challenger Ferry" that made its first flight in April 1983 (figura 2).

This dream was not realized by a series of accidents that cost the cancellation of the budgets of this project, and on the other hand, it turned out that the Moon was a more dangerous destination than had been considered, it is continually haunted by meteorites and intense waves of solar radiation, same reason why it was ruled out to locate a space shuttle from the moon, because of the high cost of survival and maintenance (for each day that an astronaut stays on the Moon it would cost something around 22 million dollars).

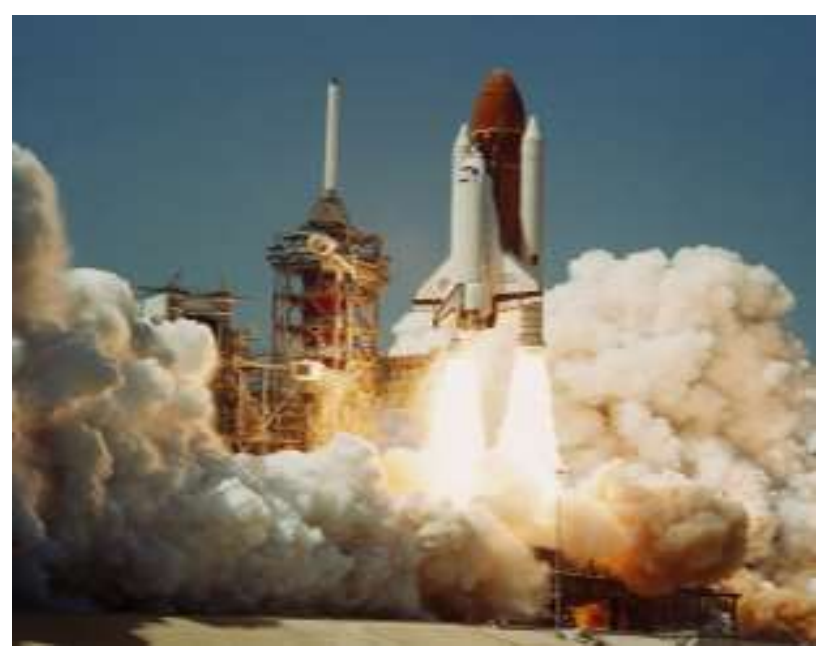

Figure 2 First launch of the shuttle Challenger in 1983

BORTONI-ANZURES, Liborio \& HERRERA-RIVAS, Hiram. Space migrants. ECORFAN Journal-Republic of Paraguay. 2019. 
Very recently with the incursion of the Entrepreneur Elon Musk in the space race, some of these plans have been dusted off and it seems that they have returned to the work tables, at least they seem to be in consideration. For now it is scheduled that by 2023 with his company SpaceX take a Japanese tourist to go around the Moon.

\section{Objective: Mars}

\section{Why go to Marte?}

Going to Mars could be considered as a step more asia the objective that the earthlings become a race capable of traveling through the galaxy and founding colonies in various worlds where our civilization can survive and perpetuate.

But there are definitely intermediate goals that do not stop being interesting. Robert Zubrin is an aerospace engineer who argues the need to go to the red planet in a conference he gave in 2018.:

"Mars was initially warm and contained liquid water on its surface for more than 100,000 years, which is five times the time it took Earth to emerge after it had it. So if the theory that life is a natural development of certain chemical components is correct, that is, if you have liquid water and certain elements long enough, life should have also appeared on Mars even though it then went extinct. And if we could go to Mars and find fossils there it would be proven that the development of life is a phenomenon that occurs throughout the Universe.

Or if we go to Mars and there is proof of the existence of water, but no fossil, it could indicate that the development of life is not a natural process that occurs with great probability, but rather a process that requires a random component and we could be alone in the Universe.

Also, if we go to Mars and drill its surface we could find liquid water that could contain life at this very moment, and if we could examine its biological composition we would determine if life on Mars is the same as that which exists on Earth because all terrestrial life has the same biochemical composition: we all share amino acids, we have DNA, RNA, etc.
Is this life? Or can life be very different from this?, Are we life, or are we an example of multiple possibilities of life? "

Each agency or country pursues its own goals, some are satisfied to cover their communication needs of meteorological monitoring, while others seriously consider escaping the Earth to settle even beyond our solar system.

\section{Participants}

The National Administration of Aeronautics and Space (NASA) founded in July 1958 has made all the developments and research related to space by the United States, monopolizes the entire budget (about 20 billion dollars per year) and flow of information, it is worth mentioning that Astronaut calls the person trained to travel to space.

The Russian Federal Space Agency, known as ROSCOSMOS, founded in February 1992 in the Soviet counterpart specializing in taking Cosmonauts into space, grabbed the beginning of the race to space, Russia and the USA were stepping on each other's feet, for some time was delayed the Soviet Union but managed to put into orbit the first space station (MIR in 1986) are now allies in the project of the international space station (first module launched in 1998), however Russia has plans to orbit its own space station.

China, India, Spain, Italy, France, Canada, Japan, Belgium, Holland, Denmark, Norway, Germany, Great Britain, Sweden, Switzerland, Brazil, the Arab Emirates and Mexico have their own space agencies, some who are interested in be part of the conquerors of space and others with somewhat more modest purposes, focused on communications and meteorology.

And privately BLUE ORIGIN by Jeff Bezos, SPACEX by Elon Musk, Russian mogul Yuri Milner and his project BREAKTHROUGH STARSHOT, Paul Allen with STRATOLAUNCH, VIRGIN GALACTIC by Richard Branson, and the company BOEING who by the way announcement in 2017 that would reach Mars before SpaceX. 
The sum of the efforts, sharing achievements and knowledge could provide results in a shorter term, maximize efficiency and gradually reduce operating costs. In addition to the technological and economic contributions to society.

\section{About the Trip}

The vehicle

One of the first elements to consider in order to make a trip to another planet is the development of the means of transport, with enough load capacity, which is fast and primarily has the capacity to make the trip back and forth.

With the current technology it requires 500 tons of solid fuel to propel us up to Mach 23 for 480 seconds, and this is necessary only to escape the Earth's atmosphere.

This fuel is composed of propellant oxidant, ammonium perchlorate, which makes up $69.93 \%$ of the mixture. The fuel is pulverized aluminum (16\%), with iron oxidizer powder (0.07) as a catalyst. The substance that holds the mixture together is polybutadiene acrylic acid acrylonitrile (12.04\%). In addition, the mixture contains a preservative glue agent $(1.96 \%)$. Each Kilogram that tries to take out of the atmosphere requires an investment of 25 million pesos.

But we still do not have a propulsion system, not only that it was sustainable simply that it could work in space or in other atmospheres, if we consider being able to make a return trip.

On the other hand, the development of new technologies in engines has some collateral damage as important levels of air pollution and a large generation of solid waste on land and in space.

Recorded since 1957, more than 5400 rockets have been launched into space (without counting failed launches), which added to damaged or out-of-use satellites result in approximately two million pieces orbiting the atmosphere at speeds of up to $28,000 \mathrm{~km} / \mathrm{h}$ (called Debris) that are an increasing risk for the following vehicles that try to go out into space.
Currently it is considered that they add more than 800 tons.

Travel time

For some time, all missions must be suicidal, at least until there is a propulsion system that can be re-used from Mars to return, but surely this obstacle will be saved at some point, leading to a second problem:

Since the orbits of the earth and Mars, are not coplanar and also differ in duration, and mainly, that our entire solar system is moving through the galaxy, it is definite that we can not make the trip at any time.

Every three years the Earth and Mars become as close as possible to their trajectories, with a distance of around 55 million kilometers, 180 days of uninterrupted travel considering current technology.

With that travel time, it is not possible to consider an immediate return, the crew should remain on mission for three years, waiting for the orbits to approach again, and later, another 180 days on the return trip.

In short, a mission with return to earth would last about 4 years.

Loading capacity

How many people would man the ships? What combination of skills will be necessary? In the journey to the unknown, a pilot, a navigator, an engineer in maintenance, a doctor (with all specialties), a psychologist are surely required, a nutritionist, archaeologist, expert in linguistics, some experts in tactics and weapons, some pawns for rough work.

In addition to the accumulated weight of each traveler and some of their belongings, they require space for operation, sleeping, eating and cleaning.

The human being requires to breathe a mixture of air composed of nitrogen $(78 \%)$ and oxygen $(20.9 \%)$, with the presence of $0.95 \%$ of other inert gases and $0.03 \%$ of carbon dioxide. At a rate of 8000 liters per day. 
Although in developed countries, the daily consumption of water is up to 480 liters, the World Health Organization estimates that 100 liters of drinking water per day are indispensable for the individual biological and health processes.

While a trained astronaut with liquid recovery and recovery systems can survive with 12 liters per day.

Regarding food, the current system consists of bags of dehydrated food and vacuum, these must be hydrated and heated to be consumed, it is important to emphasize that a well-balanced diet with the right amount of minerals, proteins, carbohydrates is of vital importance and calories.

It will now be necessary to consider the fuel, materials and infrastructures used on Mars, measuring equipment, analysis and laboratory, compounds and materials of the mission, tools, vehicles, solar panels, communication equipment, exploration robots and many more things.

\section{Risks during the trip}

And if something fails? How many spare parts and emergency cargo will be relevant? It should be considered that a rescue trip is completely ruled out. Practically, nothing can fail.

Radiation is the main problem faced by space travelers, generated by solar storms and cosmic rays, although the effects of radiation or its prolonged exposure have not been studied, all experts agree that it accelerates the appearance of radiation. all kinds of cancers.

Protejerse of such radiation implies the generation of powerful magnetic fields around the ship or habitat on Mars, emulating the protection on Earth, which is complicated, expensive, and in our case, heavy.

Biologically, weightlessness has an effect on the organism; first, many atronauts get to experience the Space Adaptation Syndrome, in which balance is lost because the auditory system is disoriented, causing dizziness and vomiting.
Later, in more prolonged periods, muscle mass is lost, due to the null effort required in space, which can lead to severe atrophy (which hinders movement when arriving at a place that has gravity).

We also have to face the problem of biological risks, how we would fight a pathogen that we could find, the viruses and terrestrial bacteria have evolved with humanity, but if we enter an extraterrestrial one, we are not sure of the effects that our antibiotics can have on the.

Likewise, what effects could we trigger if some kind of illness accompanies us on the trip and we infect a different ecosystem, it is a great responsibility.

Finally, what a technological difference we could find, how we would conduct ourselves when facing a hostile race or if at least we could communicate with them.

\section{Conclusion}

The idea of wandering through the confines of the universe, discovering new worlds, cultures and species, in a concept that has been closely linked with humanity since its inception, is how the planet has been populated, leaving our lands for the promise of something better, this story has been repeated in the Vicki, Phoenicians, Greeks, Europe to conquer the new world.

Many obstacles must be overcome and many technologies developed so that one day a person can already consider himself a citizen of Mars (or in any other world), however, there is no doubt that much progress has been made and like some previous dreams, this also someday it will be possible.

\section{References}

BBC Mundo. (2014, 25 noviembre). Los peligros invisibles de viajar al espacio. Recuperado 30 abril, 2019, de https://www.bbc.com/mundo/noticias/2014/11/ 141125_peligros_viajar_espacio_lp

Del Alamo, F. (2018, 13 julio). ¿Por qué debemos ir a Marte? Recuperado 28 abril, 2019, de

https://www.nuevatribuna.es/articulo/ciencia/po r-que-debemos-ir-a-

marte/20180707102212153733.html 
García Llama, E. (2015, 16 octubre). ¿Por qué es difícil ir a Marte? Recuperado 30 abril, 2019, de

https://www.elmundo.es/blogs/elmundo/apunte snasa/2015/10/16/por-que-es-dificil-ir-a-martei.html

Isasi Arce, R. (2017, 11 abril). Así se vive en la Estación Espacial Internacional | The Objective | Periodismo ethos. Recuperado 28 abril, 2019, de https://theobjective.com/further/asi-se-viveen-la-estacion-espacial-internacional/

Marín, D. (2016a, 21 septiembre). ¿Cuánto le cuesta a la NASA mandar a sus astronautas en las Soyuz rusas? Recuperado 28 abril, 2019, de https://danielmarin.naukas.com/2016/09/21/cua nto-le-cuesta-a-la-nasa-mandar-sus-astronautasen-las-soyuz-rusas/

Marín, E. (2016b, 14 octubre). Colonizar la Luna es mucho más peligroso de lo que creíamos por los bombardeos constantes de meteoritos. Recuperado 28 abril, 2019, de https://es.gizmodo.com/colonizar-la-luna-esmucho-mas-peligroso-de-lo-que-imag1787773465

Notimex. (2015, 25 noviembre). La alimentación de los astronautas en el espacio. Recuperado 30 abril, 2019, de https://www.eluniversal.com.mx/articulo/cienci a-y-salud/ciencia/2015/11/25/la-alimentacionde-los-astronautas-en-el-espacio

Pérez Ventura, J. (2018, 11 septiembre). La conquista del espacio en manos privadas: SpaceX, Jeff Bezos y Virgin | VENTURA. Recuperado 30 abril, 2019, de https://vaventura.com/divulgacion/ciencia/laconquista-del-espacio-en-manos-privadas/

Redacción AN. (2017, 11 marzo). Los 5 peligros de viajar al espacio, según.... Recuperado 30 abril, 2019, de https://aristeguinoticias.com/1103/kiosko/los-5peligros-de-viajar-al-espacio-segun-science/ 